\title{
Development of E-LKPD exposition text based on CTL class VIII Junior High School
}

\author{
F R Putra ${ }^{1}$, A Puteri², Abdurahman ${ }^{3}$ \\ \{ferdianrizky@student.unp.ac.id $\left.{ }^{1}\right\}$ \\ 1,2,3 Universitas Negeri Padang, Jl. Prof. Dr. Hamka Air Tawar Padang Sumatera Barat 25131, \\ Indonesia
}

\begin{abstract}
The purpose of this study is to describe the process of developing an electronic Student Worksheet (E-LKPD) for learning exposition text based on Contextual Teaching and Learning (CTL) which is valid (viewed in terms of content, presentation, language and graphics) and practical (seen in terms of ease of use and conformity with time) used by students of class VIII SMP. This type of research is research and development. The development model used is a 4-D model (defining, designing, developing and distributing). The subjects of this study were grade VIII students of SMP 12 Padang. The research data consists of qualitative data and quantitative data. Qualitative data was collected through filling in the E-LKPD validation questionnaire and the E-LKPD practicality questionnaire. The results of this study indicate that the E-LKPD produced is valid and practical. The value of E-LKPD validity of $85.72 \%$ is very valid category. Practicality based on teacher practicality values is $77.94 \%$ with practical and practical categories of students at $84.14 \%$ with a very practical category.
\end{abstract}

Keywords: Development, e-LKPD, exposition text, CTL

\section{Introduction}

Student writing skills in Indonesia are essential to be developed. One of the types of writing learned in Indonesian subjects is exposition text. Exposition text is a type of text that serves to express ideas or propose something based on strong arguments [1,2,3]. However, writing skills are the most difficult language skills mastered because writing is a very complex cognitive process [4].

Facts on the ground show that writing skills are still low. Research from various countries such as USA Crossley, S.A. \& McNamara, D.S. (2016); in Malaysia by Togatorop (2015); in America by Wahdan (2018); in Etiophia by Muluneh (2018); in Europe by Alfaki (2015) revealed that student writing skills are lower than other language skills. To overcome the students' low writing skills, the right solution is certainly needed $[5,6,7,8,9]$.

In Indonesia alone, exposition text writing skills of students in schools are in the category of imperfect and not yet satisfying. This is known based on the results of interviews with Ms. Maimunah, S.Pd. This is also supported by the results of research conducted by Lubis (2014) and Ariningsih (2012). The results of the study revealed that learning to write exposition text had not achieved satisfactory results $[10,11]$. 
Based on these facts, alternative solutions and problems are needed in developing the Participant Educator Worksheet (E-LKPD). The use of E-LKPD affects the learning process of students. In accordance with the Minister of Education and Culture Regulation [12] concerning Basic and Secondary Education Process Standards which states that learning planning includes the preparation of plans for implementing learning and preparing media and learning resources. Related to this, a worksheet for the participants in the education department is needed that can help students become creative, active and independent by finding and discovering a concept or principle for themselves that has not been previously known. Students' thinking abilities like this can be developed by applying the learning model Contextual Teaching and Learning (CTL).

Contextual Teaching and Learning (CTL) is applied because it is able to explore the potential of students in a variety of ways not monotonous so that students' understanding and abilities in writing are better. Furthermore, The E-LKPD with the CTL approach was assessed to motivate students to understand the meaning of the material being studied, namely by linking the material with the context of the daily lives of students [13].

Therefore, the author will present E-LKPD which is filled with various colors in the hope of being able to arouse students' interest in learning. The other important thing is the presentation of material on E-LKPD supported by seven components that are owned by the CTL model so that learning will be more meaningful. Furthermore, the development of teaching materials in the form of worksheets of educated participants in the exposition text writing material is expected to be able to answer the problems found in the exposition text learning class VIII junior high school students. The development of this student worksheet is designed as an alternative to help the learning process interesting. Besides being interesting, the worksheets of participants participating in the CTL model are also expected to be a valid and practical tool to use.

The standard of education and secondary processes which states that the preparation of learning tools is part of learning planning. Learning planning in question is an activity in the form of preparing tools that will help the learning process such as RPP and E-LKPD. The RPP and E-LKPD are adjusted to the approach that will be used [14].

E-LKPD is one of the teaching aids in the form of sheets containing tasks that must be done by students $[15,16]$. There are four functions of E-LKPD, as follows. First, as a teaching material that can minimize the role of educators, but more activate students. Second, as teaching material that makes it easier for students to understand the material provided. Third, as a teaching material that is concise and rich in tasks to practice. Fourth, facilitate the implementation of teaching to students [16].

In order for E-LKPD to be more meaningful, a learning model of Contextual Teaching and Learning (CTL) is used. CTL is learning that enables the learning process where students use their academic understanding and abilities in various contexts inside and outside the school to solve problems that are simulative or real, both individually and together $[17,18]$.

\section{Method}

This research is research and development because in the research that will be carried out, an implementation plan for learning electronic student worksheets (E-LKPD) based on contextual teaching and learning (CTL) is developed on exposition writing skills in VIII grade junior high school students in the city. Padang. The E-LKPD development process was carried out following the 4-D model suggested by Thiagarajan and Semmel (in Trianto 2012). The 4-D model consists of four stages of development, namely define, design, develop, and disseminate. The product trial was conducted at one of the junior high schools in the city of Padang, namely grade VIII students of SMP 12 Padang. Data generated from trials in the form of an assessment 
of the product being tested is collected through the development instrument. The instruments used in data collection in this study are validation instruments and practical instruments.

Data analysis techniques are carried out by describing validity and practicality. Validation results from the validator on all aspects assessed from the validator in the form of a table, and then look for the average score using the formula. Then, find the average score of the final value of all validators with the formula. Then, the validity level criteria can be seen in table 5 as follows.

Table 1. Criteria for level of validity.

\begin{tabular}{cl}
\hline Percentage $(\%)$ & Criteria \\
\hline $86-100$ & very valid \\
$75-85$ & valid \\
$41-74$ & quite valid \\
$21-40$ & less valid \\
$0-20$ & invalid \\
\hline
\end{tabular}

Questionnaire data was obtained by calculating the scores of students who answered each item as contained in the questionnaire. The E-LKPD practicality test data was analyzed by formula percentage. Then the average of all students will be searched by formula. The results obtained are interpreted using the following criteria.

Table 2. Criteria for practicality.

\begin{tabular}{cc}
\hline Percentage $(\%)$ & Criteria \\
\hline $0 \leq N A \leq 20$ & not practical \\
$21<N A \leq 40$ & less practical \\
$41<N A \leq 74$ & quite practical \\
$75<N A \leq 85$ & practical \\
$86<N A \leq 100$ & very practical \\
\hline
\end{tabular}

\section{Result and Discussion}

\subsection{Define}

The defining stage of the development of the E-LKPD consists of three steps, namely the initial analysis, student analysis, and task analysis. Meanwhile, content structure, concept analysis, and formulation of objectives, are included in the task analysis section. Found deficiencies related to exposition text writing, namely learning resources. Therefore, students need to have practical learning resources to support learning to write exposition texts. Thus, students can understand the material and do the exposition text writing exercises well. One learning resource that can be used is E-LKPD learning. E-LKPD learning must be in accordance with the needs of students, and can arouse the motivation of students to learn.

\subsection{Design}

The preparation of the E-LKPD begins with finding the various references needed. After that, design the E-LKPD outline, and design it to have an attractive appearance. The preparation of the E-LKPD framework is adjusted to the Contextual Teaching and Learning (CTL) learning model. The placement of CTL steps can be seen in the framework of the E-LKPD skilled in writing exposition text in the following table. 
Table 3. Framework of E-LKPD learning to write exposition text based on CTL.

\begin{tabular}{|c|c|}
\hline Preliminary Framework & Fill in the Introduction Framework \\
\hline $\begin{array}{l}\text { A. Core } \\
\text { Competencies }\end{array}$ & $\begin{array}{l}\text { Core competencies are used as a reference for compiling the } \\
\text { contents of the E-LKPD }\end{array}$ \\
\hline $\begin{array}{l}\text { B. Basic } \\
\text { Competencies }\end{array}$ & $\begin{array}{l}\text { Basic competencies are used as a reference for compiling the } \\
\text { contents of the E-LKPD }\end{array}$ \\
\hline C. Orientation & Presentation of important points learned by students. \\
\hline D. Prerequisites & Terms that must be met before studying E-LKPD. \\
\hline $\begin{array}{l}\text { E. Instructions for } \\
\text { use and time }\end{array}$ & $\begin{array}{l}\text { Guide on how to use E-LKPD for students and the amount of } \\
\text { time needed to study E-LKPD. }\end{array}$ \\
\hline $\begin{array}{l}\text { Learning Activity } \\
\text { Framework }\end{array}$ & Fill in the Learning Activity Framework \\
\hline $\begin{array}{l}\text { A. Basic } \\
\text { Competence }\end{array}$ & $\begin{array}{l}\text { Basic competencies are used as a reference for preparing the } \\
\text { contents of the E-LKPD. }\end{array}$ \\
\hline B. Indicator & Competencies that must be achieved by students every learning. \\
\hline $\begin{array}{l}\text { C. Learning } \\
\text { objectives }\end{array}$ & Statement that students want to achieve every learning activity. \\
\hline $\begin{array}{l}\text { D. enefits of } \\
\text { learning } \\
\text { activities }\end{array}$ & Benefits obtained by students every learning activity. \\
\hline $\begin{array}{l}\text { E. Description of } \\
\text { material }\end{array}$ & Contains material relating to indicators. \\
\hline F. Summary & $\begin{array}{l}\text { Contains a summary of knowledge, concepts, principles about } \\
\text { competencies contained in the material description. }\end{array}$ \\
\hline G. Practice & $\begin{array}{l}\text { Contains questions that aim to provide students with an } \\
\text { understanding of the concepts they have just learned. }\end{array}$ \\
\hline H. Self Assessment & $\begin{array}{l}\text { Assessment of student attitudes and behaviors to measure } \\
\text { strengths and weaknesses in achieving learning goals. }\end{array}$ \\
\hline $\begin{array}{l}\text { I. Supporting } \\
\text { information }\end{array}$ & Contains additional information for students. \\
\hline
\end{tabular}

\begin{tabular}{lll}
\hline Evaluation Framework & Fill in the E-LKPD Evaluation Framework \\
\hline $\begin{array}{l}\text { A. Performance test } \\
\text { B. } \begin{array}{l}\text { Assessment } \\
\text { rubrics } \\
\text { Performance } \\
\text { tests }\end{array}\end{array}$ & $\begin{array}{l}\text { Contains instructions for working on the test that students will } \\
\text { performance, and exposition of the score. }\end{array}$ \\
$\begin{array}{l}\text { C. } \begin{array}{l}\text { Guide } \\
\text { assessing } \\
\text { performance test } \\
\text { results }\end{array} \\
\text { to }\end{array}$ & $\begin{array}{l}\text { Contains ways that can be used to calculate scores into values, } \\
\text { formulas used, and benchmark reference assessment tables. }\end{array}$ \\
\hline
\end{tabular}


Based on the analysis carried out on the answer validator on the validation sheet, the results obtained as shown in the following table are obtained.

Table 4. Results of expert E-LKPD validation.

\begin{tabular}{lllll}
\hline No. & Rated aspect & Earnings Score & Validity (\%) & Category \\
\hline 1 & Feasibility of the contents of E- & 89,33 & 93,05 & Very valid \\
& LKPD & & & \\
2 & E-LKPD language & 32,00 & 100,00 & Very valid \\
3 & Presentation of E-LKPD & 94,66 & 95,33 & Very valid \\
4 & Layout of E-LKPD & 42,00 & 87,50 & Very valid \\
\hline \multicolumn{2}{l}{ Total } & 257,99 & $93,97 \%$ & Very valid \\
\hline
\end{tabular}

Based on the data analysis, the validity of the exposition text E-LKPD was $93.97 \%$ with a very valid category. The description of the validity values of each validated aspect is as follows. First, the validation of the feasibility aspect of the E-LKPD content is $93.05 \%$ with a very valid category. Second, the validation of language aspects E-LKPD is $100 \%$ with very valid categories. Third, the validation aspect of the presentation of E-LKPD is $95.33 \%$ with a very valid category. Fourth, the validation of the E-LKPD graphics aspects is $87.50 \%$ with a very valid category. To be clearer, the level of achievement or percentage of each aspect can be seen in the following figure.

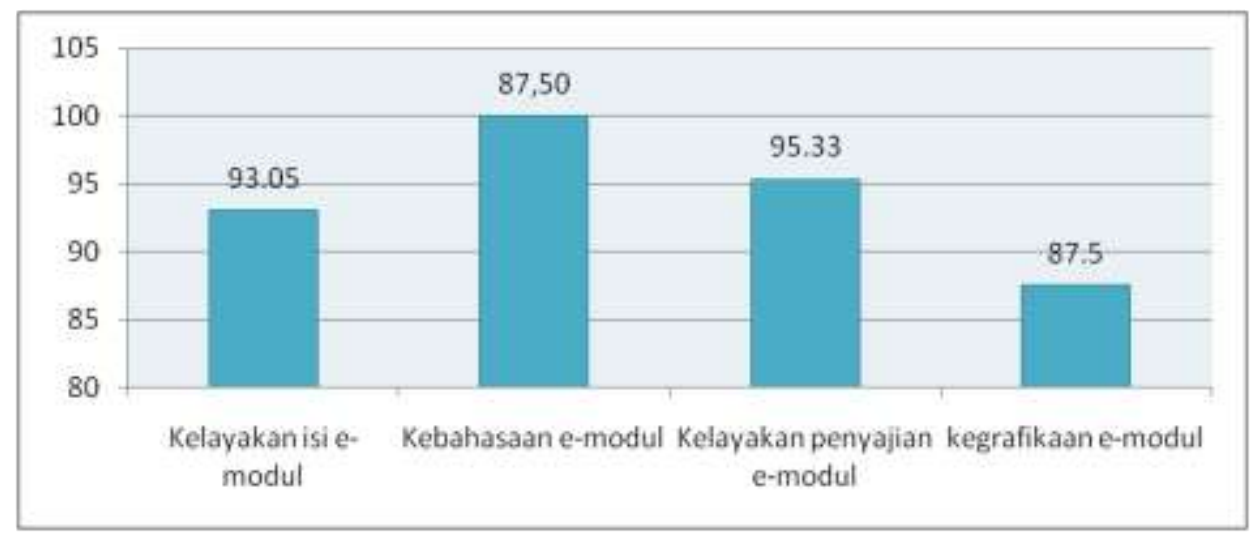

Figure 1. The level of achievement or percentage of each aspect.

Based on the results of the feasibility validation of the E-LKPD contents, it can be stated that the contents of E-LKPD are in accordance with the applicable curriculum, namely the 2013 curriculum. Contextual teaching and learning used as the E-LKPD base has been well integrated. Based on this description, it is necessary to state that the competent contents of the E-LKPD are feasible and can be used for the product testing phase. This can be seen from the value of the ELKPD validity and no comments related to the contents of the E-LKPD.

Validation of E-LKPD on linguistic aspects, namely providing assessment and improvement with sentences, punctuation, and typing letters. Based on the results of language validation, the language of E-LKPD is in accordance with EBI and good and correct language. However, there are still some typos, such as the misuse of capital letters.

Based on the results of the validation on the presentation aspects of E-LKPD, information was obtained that the presentation of E-LKPD obtained information that the presentation of E-LKPD 
was arranged according to the structure, namely the introduction, learning activities, and evaluation. The instructions for using the E-LKPD already contain a statement that makes it easy for students to use the E-LKPD. the material has also been presented in accordance with the curriculum and student needs. In addition, the evaluation presented at the end of the learning activity is in accordance with the learning objectives achieved by students.

Validation of E-LKPD grammar is an assessment of E-LKPD display. These include cover design, and content design. According to the graphic validator, overall the E-LKPD has an attractive appearance and can be said to be a feasible E-LKPD. However, there are several things that need to be improved to maintain the aesthetic value of the E-LKPD for E-LKPD users.

\subsubsection{Practicality of E-LKPD Skills for Writing Exposition Text}

Table 5. Practicality of E-LKPD by teachers/practitioners.

\begin{tabular}{llll}
\hline No. & Assessment Aspect & $\begin{array}{l}\text { Practicality Value } \\
(\%)\end{array}$ & Category \\
\hline 1. & Ease of use & 52,00 & Practical \\
\hline $2 . \quad$ Time used & 10,00 & Practical \\
\hline Overall E-LKPD Practicality & 85,00 & Practical \\
\hline
\end{tabular}

After analyzing the E-LKPD practical questionnaire filled in by practitioners, it was obtained a practical value of $85.00 \%$ with practical categories. This value is obtained from the calculation of the score of each indicator of practicality. First, the ease of use has a practical value of $86.66 \%$ with a very practical category. Second, the time used has a value of practicality of $83.33 \%$ with a very practical category. To be clearer the practicality of each of these indicators can be seen in the following picture.

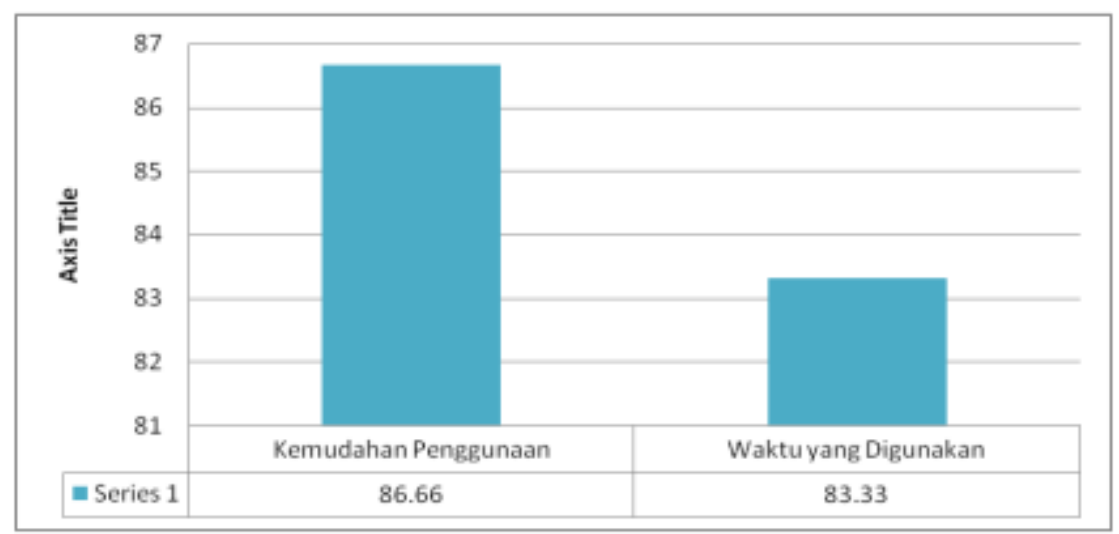

Figure 2. The practicality level of each indicator by the teacher.

Table 6. Practicality of E-LKPD by students.

\begin{tabular}{llll}
\hline No. & Assessment Aspect & $\begin{array}{l}\text { Practicality } \\
\text { Value }(\%)\end{array}$ & Category \\
\hline 1. & Ease of use & 86,66 & Very Practical \\
2. $\quad$ Time used & 83,33 & Very Practical \\
Overall E-LKPD Practicality & 85,00 & Very Practical \\
\hline
\end{tabular}


After analyzing the E-LKPD practical questionnaire filled in by students, it was obtained a practical value of 85.00 with very practical categories. This value is obtained from the calculation of the score of each indicator of practicality. First, the ease of use has a practical value of $86.66 \%$ with a very practical category. Second, the time used has a value of practicality of $83.33 \%$ with a very practical category. To be clearer the practicality of each of these indicators can be seen in the following picture.

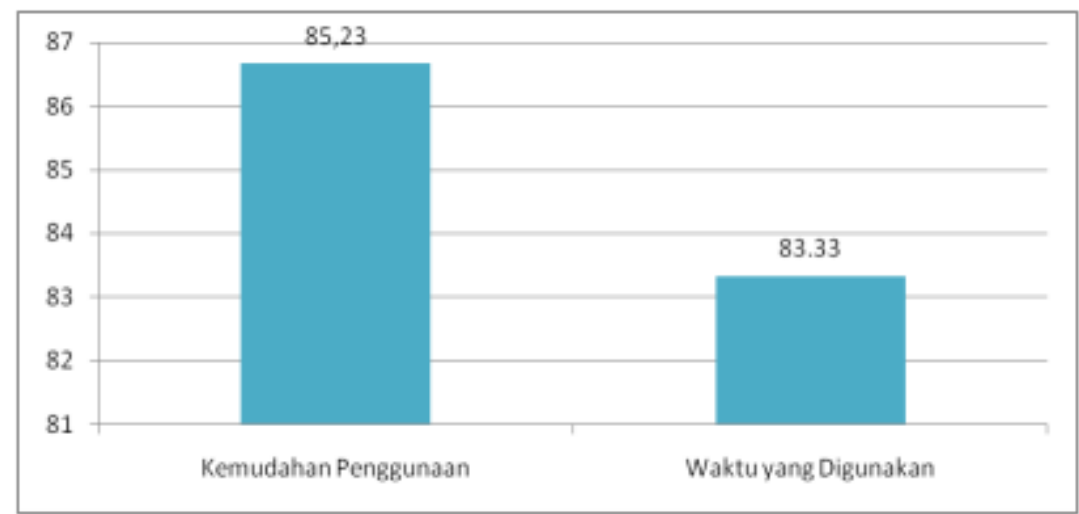

Figure 3. The level of practicality of each indicator by students.

Table 7. Student learning activities.

\begin{tabular}{lllll}
\hline No. & Statement & $\begin{array}{l}\text { Frequency } \\
\text { Activities }\end{array}$ & $\begin{array}{l}\text { of } \\
\text { Percentage } \\
\text { of Activities }\end{array}$ & Categories \\
\hline 1 & Study the E-LKPD instructions & 25 & 100 & Very active \\
2 & Constructivism & 25 & 100 & Very active \\
3 & Inquiry & 24 & 96 & Very active \\
4 & Asking & 23 & 92 & Very active \\
5 & Learning Society & 24 & 96 & Very active \\
6 & Modeling & 23 & 92 & Active \\
7 & Reflection & 21 & 84 & Very active \\
8 & Take the test writing description & 25 & 100 & Very active \\
& text. & & & \\
\hline \multicolumn{2}{l}{ Total } & 190 & 760 & Very active \\
\hline Average & & 95 & Very active \\
\hline
\end{tabular}

The results of the analysis of the observation sheet of student activities show that student learning activities using E-LKPD are categorized as very active. It was seen from the acquisition of the average value of the percentage of overall student activity by $93.33 \%$ with a very active category. The way to get these results is to summarize the frequency of activities for each observation item contained in the observation sheet.

\section{Conclusions and Suggestions}

Based on the results of the development that has been carried out, the following points can be concluded. The process of developing the E-LKPD that has been carried out includes four stages, namely defining, designing, developing and disseminating. This development process 
produces products in the form of E-LKPD learning exposition text writing based on contextual teaching and learning that is valid and practical.

The process of developing the E-LKPD at the develop stage. E-LKPD learning to write exposition text based on contextual teaching and learning which is developed is very valid category. The validity of the E-LKPD is illustrated by the results of the validation by experts on the four aspects of E-LKPD validation, namely the feasibility aspects of content, language, presentation, and graphics. This can be seen from the validity of this learning E-LKPD with the acquisition of the E-LKPD validity value as much as 85.72 with a very valid category. E-LKPD learning exposition text writing based on contextual teaching and learning developed in a very practical category. Practicality of E-LKPD by teachers is $77.94 \%$ with practical categories. Meanwhile, the practicality of E-LKPD by students is $84.14 \%$, with a very practical category.

As for suggestions related to E-LKPD learning aimed at students, students, and subsequent researchers. First, through the results of the development of this E-LKPD, students are expected to be able to take advantage of learning E-LKPD writing exposition text based on contextual teaching and learning as a model for developing teaching materials in learning materials in Indonesian Curriculum 2013. Second, the results of product development in the form of ELKPD learning to write exposition text based on CTL, is expected to help students master three competencies (attitudes, knowledge, and skills) in learning to write exposition text. Third, the results of this development study can be used as a comparison material or as a reference to consider and implement good development research related to writing exposition texts and CTL learning models.

\section{References}

[1] Mahsun 2014 Teks dalam Pembelajaran Bahasa Indonesia (Jakarta: PT Raja Grafindo Persada)

[2] Priyatni E T 2014 Desain Pembelajaran Bahasa Indonesia dalam Kurikulum 2013 (Jakarta: Bumi Aksara)

[3] Suparno and Yunus M 2008 Keterampilan Dasar Menulis (Jakarta: Universitas Terbuka)

[4] Sibarani B 2007 Penerapan Proses Kognitif dan Terapi Cognitive Blocking dalam Peningkatan Kualitas Pembelajaran Menulis vol 14 (Medan: Diksi) pp. 132-142

[5] Crossley S A and McNamara D S 2016 Say More and Be More Coherent: How Text Elaboration and Cohesion Can Increase Writing Quality Vol 7 (USA: Journal of Writing Research) pp. 351-370

[6] Togatorop E 2015 Teaching Writing with A Web Based Collaborative Learning Vol 5 (Kuala Lumpur: Econ Journals) pp. 247-256

[7] Wahdan N R 2018 Investigating The Effects of Using Writing Process On Students' Writing Performance at Foundation Program- Hai'l University Vol 10 (Perlis: International Journal of Linguistics) pp. 14-20

[8] Muluneh T K 2018 Improving Students' Paragraph Writing Skill Through Task Based Approach Vol 9 (Ethiopia: Arts and Social Sciences Journal) pp. 1-4

[9] Alfaki I M 2015 University Students' English Writing Problems: Diagnosis and Remedy Vol 3 (UK: International Journal of English Language Teaching) pp. 40-52

[10] Lubis R S 2014 Pengaruh Model Pembelajaran Berbasis Inkuiri Terhadap Kemampuan Menulis Teks Eksposisi oleh Siswa Kelas X SMA Negeri 5 Medan Tahun Pelajaran 2013/2014 Vol 3 (Medan: Journal Penelitian Pendidikan Universitas Medan) p 1 
[11] Ariningsih N E 2012 Analisis Kesalahan Berbahasa Indonesia dalam Karangan Eksposisi Siswa Sekolah Menengah Atas Vol 1 (Surakarta: BASASTRA Jurnal Penelitian Bahasa, Sastra Indonesia dan Pengajarannya) pp. 40-52

[12] Permendikbud Republik Indonesia Nomor 202016 Tentang Standar Kompetensi Lulusan Pendidikan Dasar dan Menengah

[13] Wirdaningsih S 2017 Pengembangan Perangkat Pembelajaran Dengan Pendekatan Contextual Teaching And Learning Untuk Meningkatkan Kemampuan Pemecahan Masalah Peserta Didik Kelas XI Vol 1(Cirebon: Jurnal JNPM (Jurnal Nasional Pendidikan Matematika) p 275

[14] Permendikbud Republik Indonesia Nomor 692013 Tentang Kerangka Dasar dan Struktur Kurikulum Sekolah Menengah Atas/Madrasah Aliyah

[15] Majid A 2013 Strategi Pembelajaran (Bandung: PT Remaja Rosdakarya Offset)

[16] Prastowo A 2011 Panduan Kreatif Membuat Bahan Ajar Inovatif (Yogyakarta: Diva Press)

[17] Rusman 2012 Model-Model Pembelajaran (Jakarta: Rajawali Pers)

[18] Trianto 2012 Mendesain Model Pembelajaran Inovatif-Progresif(Jakarta:Kencana)

\section{Acknowledgments}

This article was realized thanks to help from various parties. The author would like to thank all parties who are willing to contribute data to this article. The author also thanked the Lecturer who has given criticism and suggestions for the perfection of this paper. 